\title{
DAERAH PENANGKAPAN POTENSIAL IKAN TENGGIRI (Scomberomorus sp) BERDASARKAN PARAMETER SUHU PERMUKAAN LAUT DI KABUPATEN PANGANDARAN
}

\author{
Potential Fishing of Fishing Catch for Tenggiri (Scomberomorus sp) Based on Sea Surface \\ Temperature Parameter in Pangandaran District
}

Oleh:

\author{
Mia Kusmiati ${ }^{1}$, Zahidah ${ }^{1}$, Ibnu Dwi Buwono ${ }^{1}$ dan Izza Mahdiani Apriliani ${ }^{1}$ \\ ${ }^{1}$ Fakultas Perikanan dan Ilmu Kelautan, Universitas Padjadjaran, Indonesia \\ Korespondensi: kuskusmia12@gmail.com
}

\begin{abstract}
ABSTRAK
Penelitian ini bertujuan untuk mengetahui daerah penangkapan potensial ikan tenggiri (Scomberomorus sp) berdasarkan parameter suhu permukaan laut (SPL) di perairan Kabupaten Pangandaran. Metode yang digunakan dalam riset ini adalah metode survei. Data penelitian meliputi SPL yang diperoleh dari citra satelit serta hasil tangkapan dan koordinat penangkapan yang didapat dari trip langsung. Hasil penelitian menunjukkan bahwa sebaran temporal suhu permukaan laut tertinggi cenderung terjadi pada musim peralihan 1 (Maret-Mei). Sebaran suhu permukaan laut cenderung memiliki pola semakin dingin menuju perairan lepas pantai dan semakin hangat menuju perairan pesisir pantai. Daerah potensial penangkapan ikan tenggiri di perairan Pangandaran berada pada koordinat pada koordinat $108^{\circ} 21^{\prime} 18^{\prime \prime}$ BT, $7^{\circ} 50^{\prime} 58^{\prime \prime}$ LS dan $108^{\circ} 44^{\prime} 30^{\prime \prime}$ BT, $7^{\circ} 48^{\prime} 31^{\prime \prime}$ LS.
\end{abstract}

Kata kunci: daerah potensial penangkapan, hasil tangkapan ikan tenggiri, perairan Pangandaran, suhu permukaan laut

\begin{abstract}
This study aims to determine the potential fishing grounds for tenggiri (Scomberomorus sp) based on sea surface temperature in Pangandaran district. The method used in this research is a survey. The research data included SPL which were obtained from satellite image as well as catches and capture coordinates obtained from trips. The results showed that the temporal distribution of the highest sea surface temperature in Transition I (March-May). Sea surface temperature distribution tends to have a colder pattern towards offshore waters and warmer towards coastal water. The coordinates of potential fishing catch of tenggiri in Pangandaran are 108'21'18" LS, $7{ }^{\circ} 50^{\prime} 58^{\prime \prime}$ BT dan 108 $44^{\prime} 30^{\prime \prime} \mathrm{LS}, 7^{\circ} 48^{\prime} 31^{\prime \prime}$ $B T$.
\end{abstract}

Key words: fishing area, tenggiri, sea surface temperature, Pangandaran

\section{PENDAHULUAN}

Kabupaten Pangandaran merupakan salah satu kabupaten yang berada di Provinsi Jawa Barat yang mempunyai garis pantai dengan panjang mencapai $91 \mathrm{~km}$ dan luas laut mencapai 67.340 ha. Kondisi geografis ini membuat sebagian masyarakatnya berprofesi sebagai nelayan, berdasarkan jumlah kartu nelayan pada aplikasi kenelayanan saampai tahun 2016 tercatat jumlah nelayan di Kabupaten Pangandaran berjumlah 996 orang yang tersebar di 8 kecamatan yaitu Cimerak, Cijulang, Parigi, Sidamulih, Pangandaran, Kalipucang, Mangunjaya, dan Padaherang. (Profil Kabupaten Pangandaran tahun 2017). 
Ikan tenggiri merupakan salah satu spesies ikan yang menjadi target tangkapan nelayan di wilayah perairan Indo-Pasifik. Ikan tenggiri mempunyai bobot hingga $45 \mathrm{~kg}$ serta panjangnya bisa mencapai panjang 3,4 meter serta jenis ikan tenggiri ini akan mencapai kondisi melimpah pada musimmusim tertentu (Jumsurizal et al. 2014).

Potensi ikan tenggiri (Scomberomorus sp) di wilayah Kabupaten Pangandaran perlu di optimalkan agar mampu termanfaatkan secara berkelanjutan. Hasil tangkapan ikan yang optimal dapat diketahui melalui informasi mengenai daerah penangkapan ikan. Informasi mengenai daerah penangkapan ikan, dapat diketahui dengan parameter oseanografi. Parameter oseanografi merupakan salah satu faktor yang mempunyai pengaruh terhadap hasil tangkapan seperti SPL yang dapat mempengaruhi penentuan DPI khususnya ikan pelagis (Putra 2012). Perubahan suhu bisa menyebabkan terjadinya sirkulasi dan stratifikasi air yang secara langsung dan tidak langsung berpengaruh terhadap distribusi organisme perairan (Almuthahar 2005).

Untuk mendukung kegiatan penangkapan ikan yang berkelanjutan, sumber daya perikanan harus dilakukan secara optimal sehingga produksi perikanan di wilayah perairan Kabupaten Pangandaran akan terus berkelanjutan (Apriliani 2019).

\section{METODE PENELITIAN}

Penelitian dilaksanakan pada bulan Agustus 2018-Januari 2019 di daerah Pangandaran. Penelitian dilaksanakan dalam dua tahap yaitu tahap pengambilan data dan pengolahan data. Tahap pengumpulan data dilaksanakan di Perairan Pangandaran dengan melakukan kegiatan eksperimental fishing dengan jumlah lima belas titik koordinat di wilayah Perairan Pangandaran, serta pengambilan data produksi hasil tangkapan ikan tenggiri pada saat trip dan data tahunan produksi ikan tenggiri. Tahap pengolahan data dengan mengunduh data citra satelit dari database NASA (oceancolor.gsfc.nasa.gov) dalam rentan waktu tiga tahun terakhir serta dianalisis regresi dan korelasi.

Pada penelitian ini alat yang digunakan diantaranya alat tulis, kamera, meteran, timbangan, GPS, perangkat lunak serta laptop, sedangkan untuk bahan yang digunakan diantaranya data sebaran SPL di perairan Kabupaten Pangandaran yang sebelumnya diperoleh dari dari Aqua-MODIS yang sebelumya telah diunduh, data produksi ikan tenggiri Kabupaten Pangandaran mulai tahun 2016 sampai 2018 dan terakhir adalah kuisioner untuk mengetahui aktivitas penangkapan ikan.

Metode yang dilakukan adalah metode survei. Data yang dibutuhkan berupa data primer dan data sekunder. Data primer diantaranya ukuran panjang dan bobot ikan tenggiri hasil tangkapan, jumlah ikan tenggiri yang tertangkap, dan posisi kapal melakukan kegiatan operasi penangkapan. Data sekunder diantaranya suhu permukaan laut dan data produksi ikan tenggiri di Kabupaten Pangandaran.

Prosedur pengolahan data yang dilakukan selama penelitian diantaranya adalah:

1. Pengumpulan data

Data yang diperoleh dari hasil wawancara, survei langsungan maupun dari data yang diperoleh dari hasil unduhan di website http://oceancolor.gsfc.nasa.gov/cms dalam rentan waktu tiga tahun.

2. Pengolahan data

Data SPL yang telah di website http://oceancolor.gsfc.nasa.gov/cms, selanjutnya diolah menggunakan software Arcgis untuk mengambil wilayah yang akan diolah dan dianalisa. Selanjutnya diolah menggunakan software pemetaan untuk memperoleh data SPL. Data produksi ikan tenggiri yang telah diperoleh, kemudian diolah kedalam bentuk grafik dan dianalisis korelasi dan regresi serta dibahas secara deskriptif.

3. Analisis penentuan daerah potensial penangkapan ikan

Pendugaan daerah penangkapan ikan (DPI) potensial ini dilihat berdasarkan beberapa parameter yaitu nilai sebaran SPL, total produksi ikan tenggiri dan rata-rata panjang ikan tenggiri. Penentuan daerah penangkapan potensial ikan tenggiri ini menggunakan metode skoring berdasarkan 
indikator tersebut. Pemberian skor terhadap masing-masing indikator parameter menentukan daerah mana yang menjadi daerah potensial penangkapan ikan. Daerah penangkapan ikan potensial adalah daerah yang memiliki skor paling tinggi berdasarkan semua indikator sedangkan DPI kurang potensial adalah daerah yang mempunyai skor penilaian kecil dari semua indikator.

Penilaian hasil tangkapan dilakukan dengan menggunakan kriteria yang disajikan pada Tabel 1 , penilaian tersebut berdasarkan rata-rata hasil tangkapan ikan tenggiri di sembilan TPI yang ada di wilayah Kabupaten Pangandaran pada tahun 2018. Rata-rata hasil tangkapan ikan tenggiri di Kabupaten Pangandaran setiap armada adalah $34 \mathrm{~kg}$, setiap armada melakukan dua kali kegiatan penangkapan setiap hari (dua titik lokasi penangkapan) sehingga di dapatkan nilai untuk standar hasil tangkapan ikan di Kabupaten Pangandaran adalah $17 \mathrm{~kg}$.

Tabel 1 Penilaian jumlah hasil tangkapan ikan tenggiri

\begin{tabular}{ccc}
\hline Jumlah Hasil Tangkapan $(\mathrm{kg})$ & Kriteria & Penilaian \\
\hline$<17$ & Sedikit & 1 \\
$>17$ & Banyak & 3 \\
\hline
\end{tabular}

Sumber: Dinas Perikanan Kabupaten Pangandaran Tahun 2017.

Penilaian kelayakan hasil tangkapan berdasarkan ukuran panjang ikan dilakukan dengan menggunakan kriteria yang disajikan pada Tabel 2, penilaian tersebut berdasarkan sebaran umum panjang ikan tenggiri matang gonad dan memijah serta layak tangkap di perairan Indonesia yaitu sebesar $42 \mathrm{~cm}$ (Restiangsih dkk 2016).

Tabel 2 Kelayakan hasil tangkapan ikan tenggiri berdasarkan ukuran panjang

\begin{tabular}{ccc}
\hline Jumlah Hasil Tangkapan (kg) & Kriteria & Penilaian \\
\hline $\mathrm{x} \geq 42 \mathrm{~cm}$ & Tidak layak tangkap & 1 \\
$\mathrm{x} \leq 42 \mathrm{~cm}$ & Layak tangkap & 3 \\
\hline
\end{tabular}

Sumber: Restiangsih dkk, 2016.

Penilaian suhu permukaan laut dilakukan menggunakan kriteria yang disajikan pada Tabel 3, penilaian tersebut berdasarkan besaran umum suhu yang optimum untuk ikan tenggiri di perairan yaitu berkisar antara $24^{\circ}-31^{\circ} \mathrm{C}$ (Nahib dkk 2010).

Tabel 3 Penilaian DPI ikan tenggiri melalui indikator SPL

\begin{tabular}{ccc}
\hline SPL & Kriteria & Penilaian \\
\hline $24^{\circ} \mathrm{C}-31^{\circ} \mathrm{C}$ & Optimum & 3 \\
$\mathrm{x}<24^{\circ} \mathrm{C}, \mathrm{x}>31^{\circ} \mathrm{C}$ & Kurang Optimum & 1 \\
\hline
\end{tabular}

Sumber: Nahib dkk 2010

\section{HASIL DAN PEMBAHASAN}

Kabupaten Pangandaran merupakan wilayah yang termasuk kedalam Wilayah Pengelolaan Perikanan (WPP) 573 yang cakupannya meliputi perairan ujung barat pulau Sumatera dan wilayah pantai selatan Jawa. Armada kapal penangkapan ikan di Kabupaten Pangandaran didominasi oleh perahu motor tempel. Kegiatan penangkapan di Kabupaten Pangandaran dilakukan di wilayah perairan Teluk Pananjung, Teluk Parigi, Karapyak, Nusakambangan dan Cilacap (Dinas Kelautan dan Perikanan Kabupaten Pangandaran 2016).

Berdasarkan data yang diperoleh dari Dinas Perikanan dan Kelautan Kabupaten Pangandaran pada tahun 2016-2018 produksi ikan tenggiri di wilayah Kabupaten Pangandaran mengalami fluktuasi 
yang beragam dan dapat mencapai produksi tertinggi sebanyak 76.045,75 kg pada tahun 2017 dan produksi terendah pada tahun 2016 sebanyak $16.263,65 \mathrm{~kg}$. Data hasil tangkapan ikan tenggiri selama kurun waktu 2016-2018 disajikan pada Tabel 4.

Tabel 4 Produksi ikan tenggiri tahun 2016-2018

\begin{tabular}{cc}
\hline Tahun & Produksi Ikan Tenggiri $\mathbf{( k g )}$ \\
\hline 2016 & $16.273,65$ \\
2017 & $76.045,75$ \\
2018 & $37.828,70$ \\
\hline
\end{tabular}

Sumber: Dinas Perikanan Kabupaten Pangandaran Tahun 2019

Hasil tangkapan ikan tenggiri rata-rata setiap bulan dalam kurun waktu 2016-2018 disajikan pada Gambar 1.

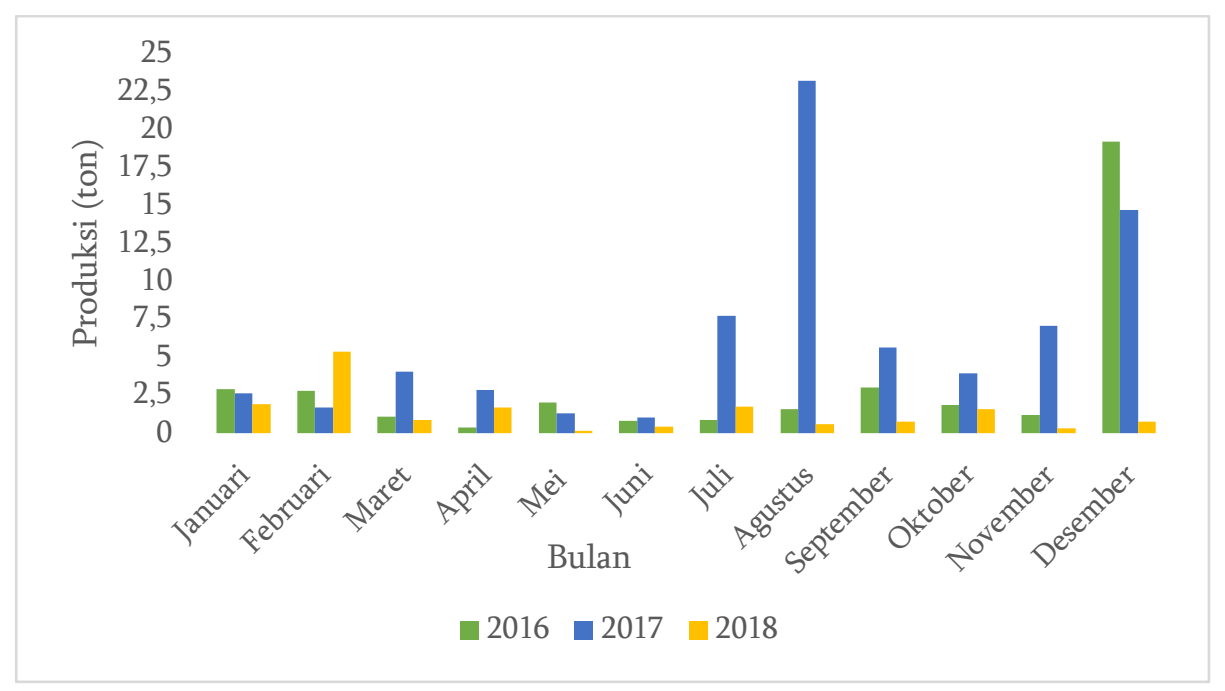

Gambar 1 Produksi bulanan ikan tenggiri di Kabupaten Pangandaran tahun 2016-2018

Berdasarkan data produksi ikan tenggiri dapat diketahui bahwa secara keseluruhan, dalam rentan waktu 2016-2018 produksi ikan tenggiri di Kabupaten Pangandaran mengalami fluktuasi setiap bulannya. Hasil tangkapan tertinggi pada bulan Agustus tahun 2017 sebanyak 23,27 ton dan jumlah hasil tangkapan terendah sebesar 0,16 ton pada bulan Mei tahun 2018. Hasil tangkapan ikan tenggiri dalam rentan waktu tiga tahun yaitu 2016-2018 ini secara garis besar menampilkan bahwa pada tahun 2017 hasil tangkapan ikan tenggiri mempunyai hasil tangkapan paling besar dibandingkan dengan tahun yang lainnya.

Hasil tangkapan ikan tenggiri di Kabupaten Pangandaran setiap bulan mengalami fluktuasi yang dapat dipengaruhi oleh faktor oseanogafis di perairan yang mempengaruhi penyebaran ikan tenggiri. Menurut Tangke (2012) sebaran ikan tenggiri di wilayah perairan Maluku dipengaruhi oleh faktor oseanografi salah satunya yaitu SPL. Perubahan hasil tangkapan ikan setiap bulan dalam kurun waktu 2016-2018 digambarkan pada grafik rata-rata hasil tangkapan pada Gambar 2.

Berdasarkan data rata-rata bulanan produksi ikan tenggiri pada tahun 2016-2018 di Kabupaten Pangandaran, pada bulan Januari hingga bulan Mei atau pada musim barat hingga musim peralihan I, hasil tangkapan ikan tenggiri cenderung stabil dan tidak berfluktuasi. Bulan Juli hingga Agustus hasil tangkapan ikan tenggiri mengalami kenaikan yang cukup signifikan dan kembali turun pada bulan September atau pada musim peralihan II. Berdasarkan hasil tangkapan bulanan ikan tenggiri selama kurun waktu tiga tahun tersebut menunjukkan bahwa musim penangkapan ikan yang disertai adanya 
sebaran oseanografi di perairan yang mendukung seperti SPL dapat mempengaruhi hasil tangkapan ikan tenggiri.

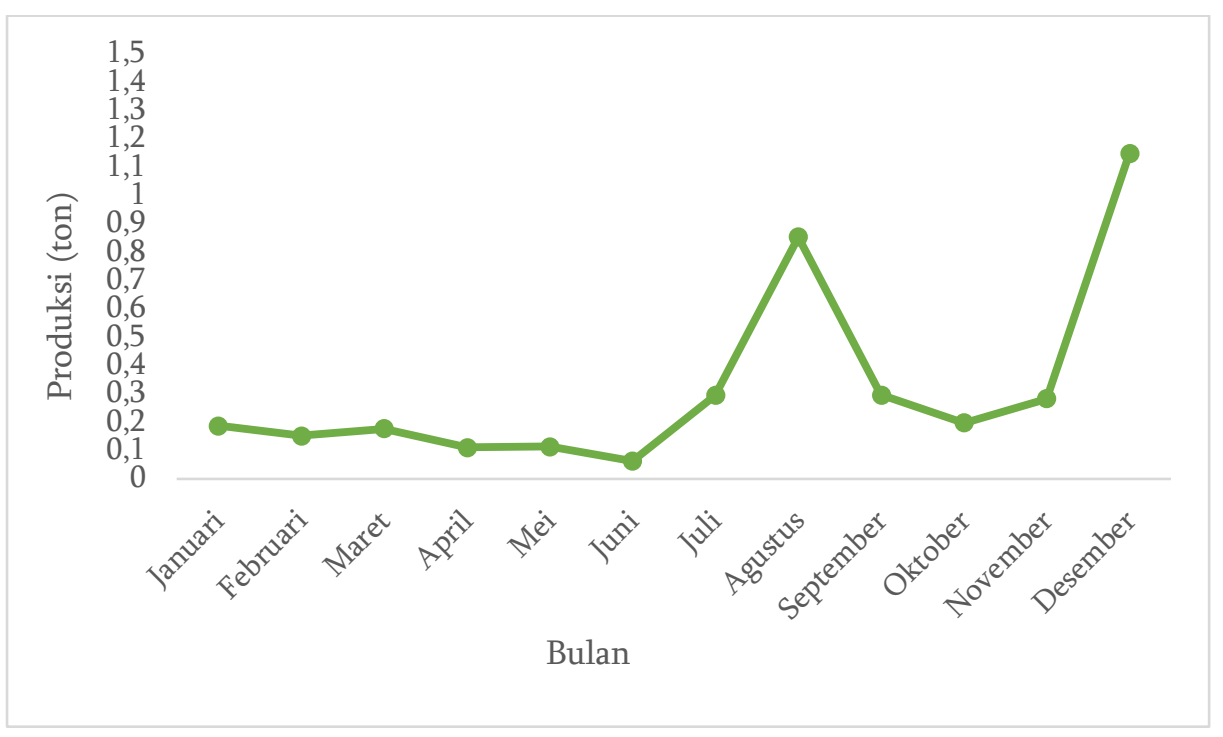

Gambar 2 Produksi rata-rata bulanan ikan tenggiri tahun 2016-2018 Gambar 3.

Produksi ikan tenggiri di Kabupaten Pangandaran sesuai musim penangkapan digambarkan pada

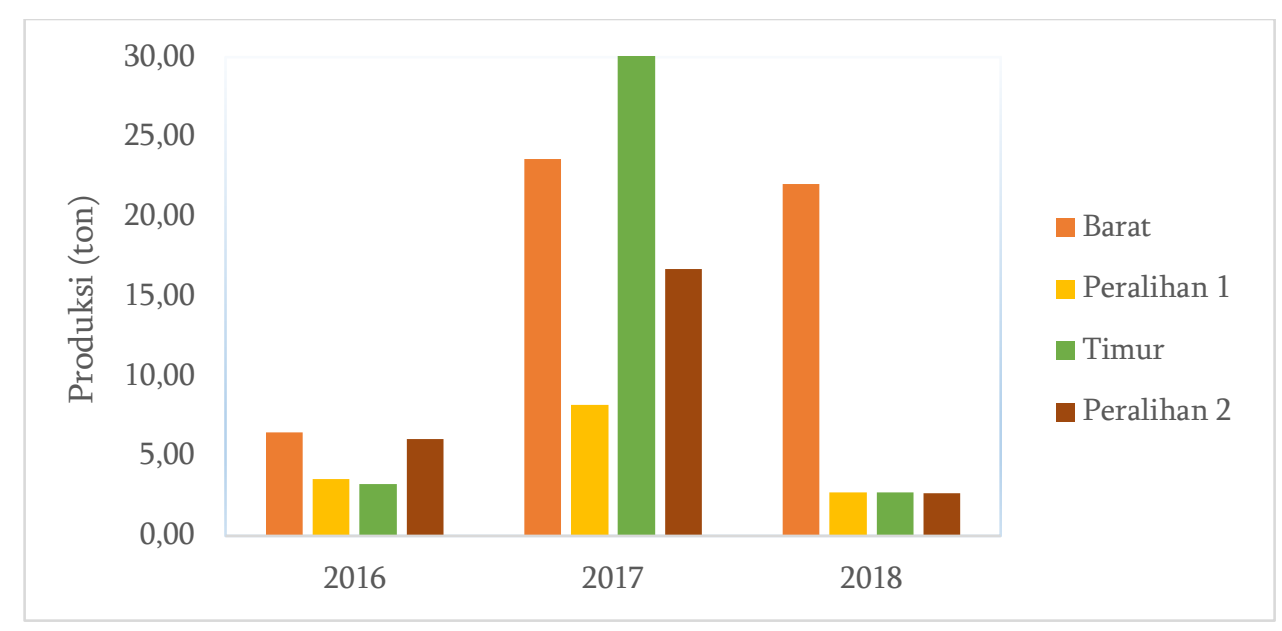

Gambar 3 Produksi musiman ikan tenggiri pada tahun 2016-2018

Berdasarkan data produksi musiman ikan tenggiri pada tahun 2016-2018 di Kabupaten Pangandaran dapat diketahui bahwa dalam kurun waktu tiga tahun terhitung dari tahun 2016-2018 puncak penangkapan ikan tenggiri di Kabupaten Pangandaran adalah pada musim barat atau dalam rentang bulan Desember-Februari dan musim timur atau dalam rentang waktu Juni-Agustus. Menurut Mutakin (2001) musim penangkapan yang merupakan waktu paling baik untuk menangkap tenggiri di Pangandaran adalah periode musim timur dan mencapai puncak penangkapan pada bulan Juli hingga Agustus. Dari data musiman produksi ikan tenggiri pada rentan waktu tiga tahun tersebut juga diketahui bahwa pada tahun 2017 produksi hasil tangkapa ikan tenggiri mempunyai hasil tangkapan yang lebih banyak daripada tahun lainnya yang dapat disebabkan faktor-faktor yang ada di lingkungan perairan Kabupaten Pangandaran seperti tinggi gelombang, suhu, klorofil-a dan lain sebagainya.

Nilai SPL dalam rentan waktu tiga tahun yaitu tahun 2016-2018 di perairan Pangandaran disajikan pada Gambar 4. 


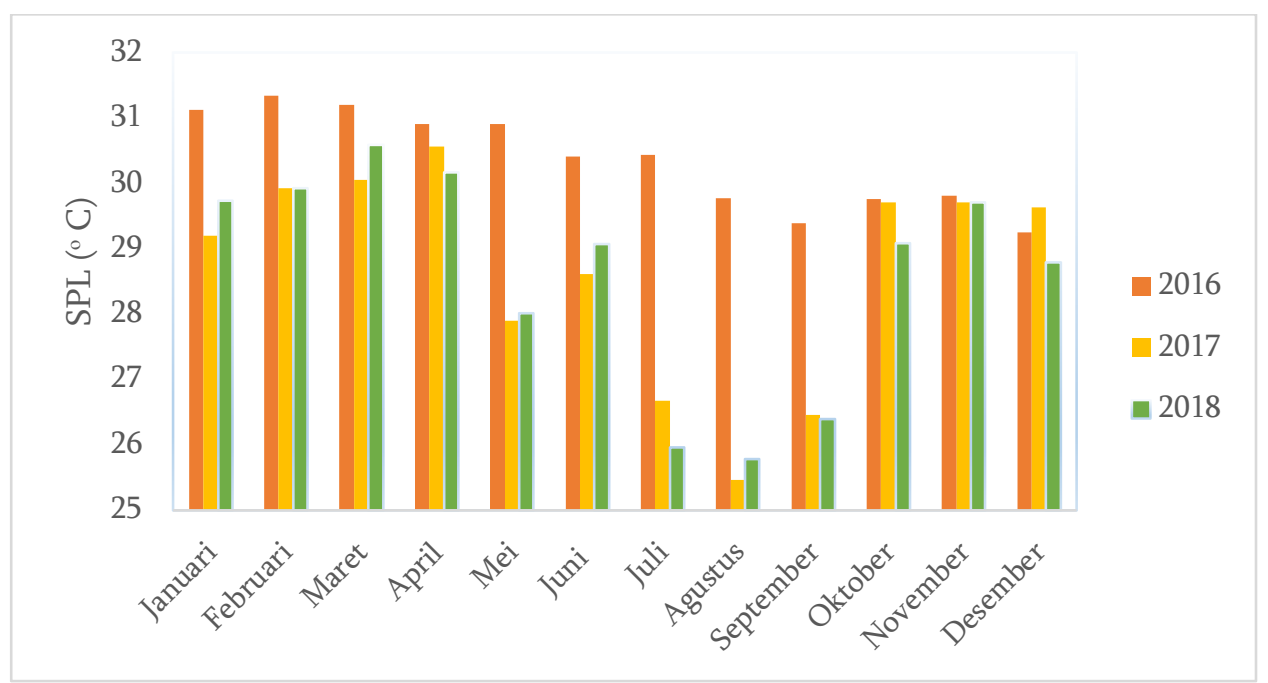

Gambar 4 Sebaran SPL di Kabupaten Pangandaran tahun 2016-2018

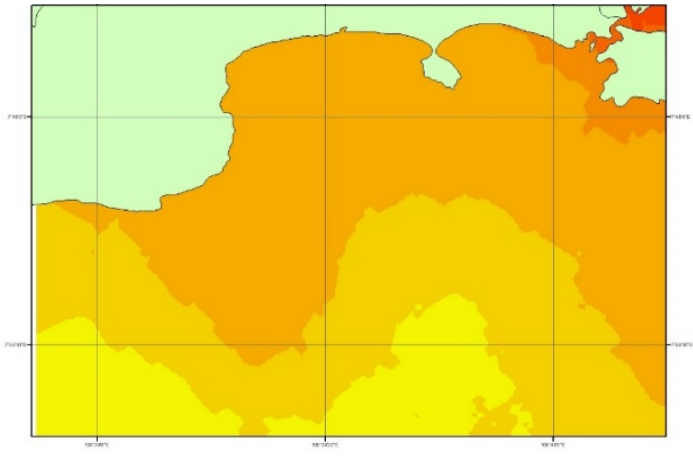

Musim barat

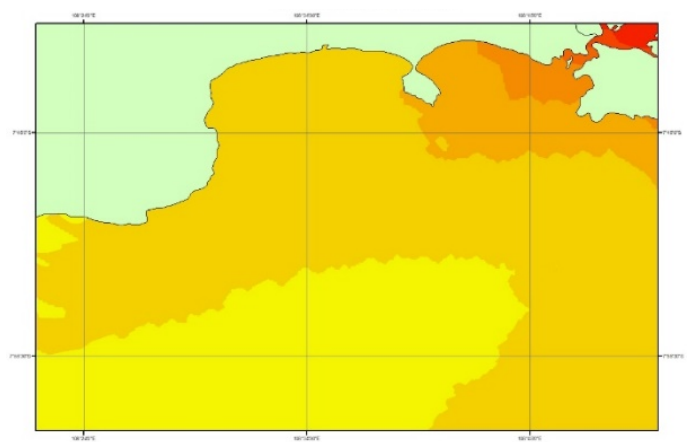

Musim timur

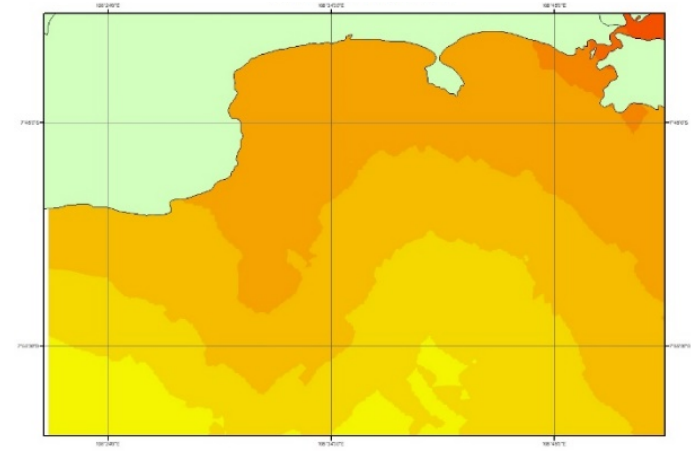

Musim peralihan I

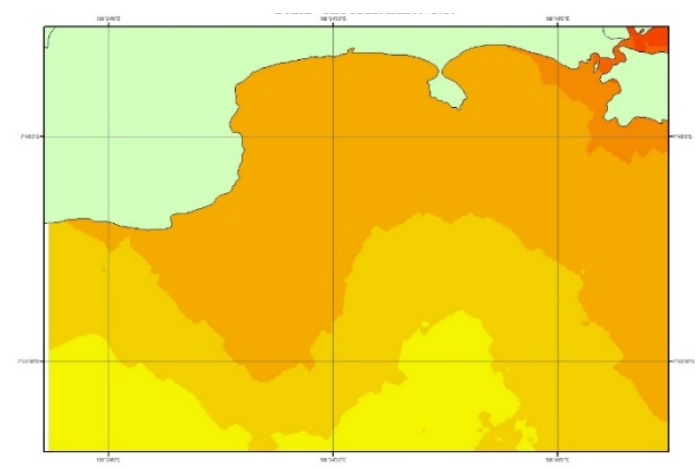

Musim peralihan II

$28,22-28,349$

$28,479-28,607$

$28,35-28,478$

$28,608-28,736$

$28,737-28,865$

$28,866-28,994$

$28,995-29,123$

$29,124-29,252$

Gambar 5 SPL musiman perairan Kabupaten Pangandaran tahun 2016

Berdasarkan grafik suhu permukaan laut bulanan tahun 2016 hingga tahun 2018 di Kabupaten Pangandaran, SPL mencapai nilai tertinggi di bulan Februari sampai bulan April atau pada musim barat dan peralihan I sedangkan nilai SPL mencapai nilai terkecil di bulan Agustus sampai September atau pada musim timur dan peralihan II. Selain itu, besaran suhu di Kabupaten Pangandaran selama kurun waktu 2016-2018 berkisar antara $25^{\circ} \mathrm{C}$ sampai $32^{\circ} \mathrm{C}$. Pada rentang suhu ini, ikan tenggiri masih bisa hidup di perairan Pangandaran. Hal ini sesuai dengan Nahib et al (2010) yang menyatakan bahwa ikan 
tenggiri dapat hidup pada rentang suhu berkisar antara $25^{\circ} \mathrm{C}$ sampai dengan $31^{\circ} \mathrm{C}$. Nilai SPL setiap musim penangkapan di Indonesia disajikan pada Gambar 5 sampai Gambar 7.

Karakteristik SPL di perairan Kabupaten Pangandaran pada tahun 2016 berkisar antara $28^{\circ}-31^{\circ} \mathrm{C}$, sedangkan untuk besaran SPL yang dominan yaitu $29^{\circ}-31^{\circ} \mathrm{C}$. Besaran SPL di Kabupaten Pangandaran pada musim peralihan I mempunyai nilai sebaran suhu yang lebih besar dibandingkan dengan musim lainnya dan musim timur mempunyai nilai SPL yang lebih kecil dibandingkan musim lainnya.

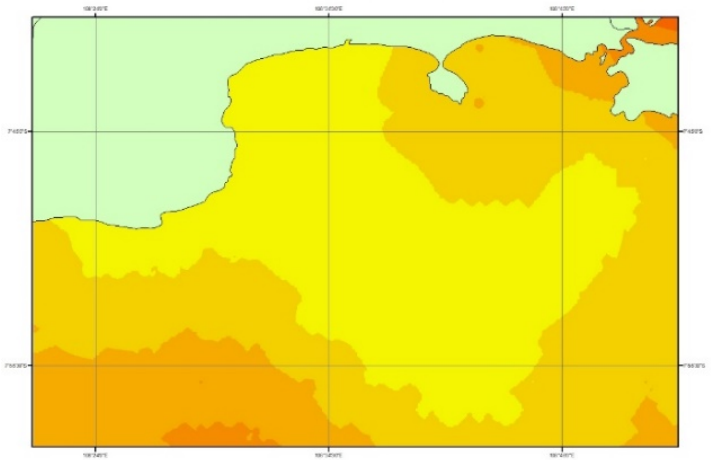

Musim barat

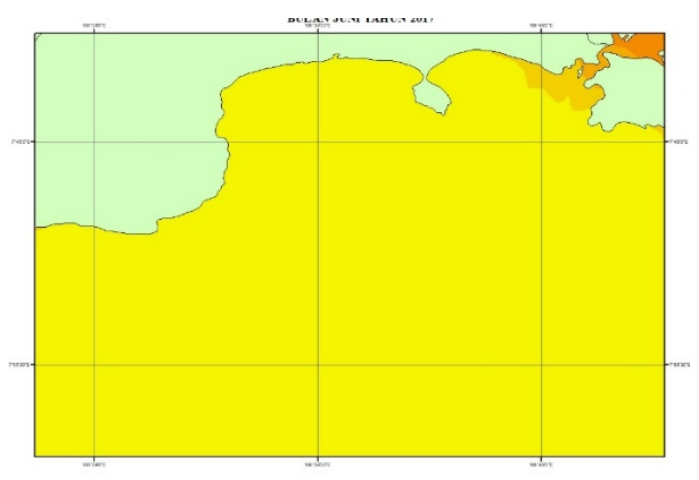

Musim timur

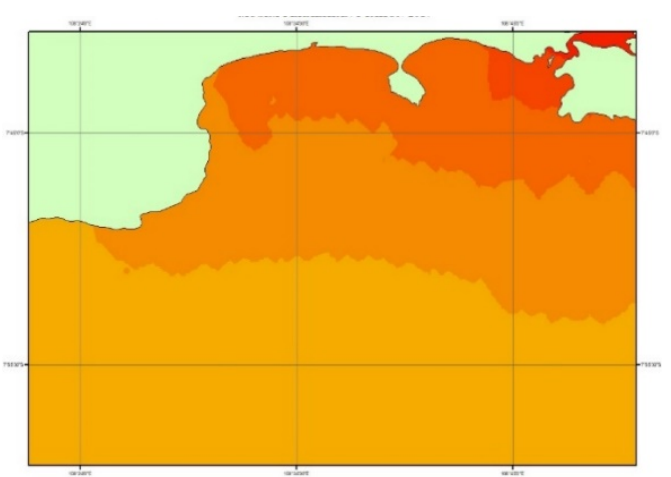

Musim peralihan I

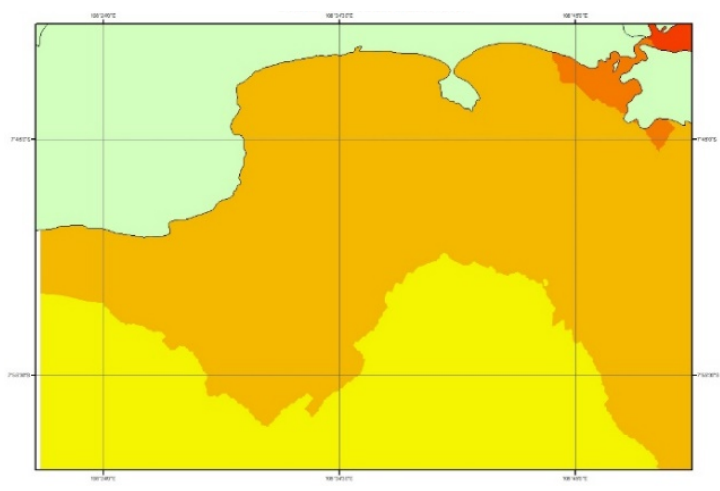

Musim peralihan II
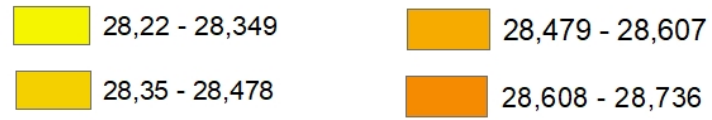

$28,737-28,865$

$28,866-28,994$

$28,995-29,123$

$29,124-29,252$

Gambar 6 SPL musiman perairan Kabupaten Pangandaran tahun 2017

Karakteristik SPL di perairan Kabupaten Pangandaran pada tahun 2017 berkisar antara $25^{\circ}-31^{\circ} \mathrm{C}$, sedangkan untuk besaran SPL yang dominan berkisar antara $26^{\circ}-28^{\circ} \mathrm{C}$. Besaran SPL pada musi peralihan I mempunyai nilai sebaran suhu tertinggi dari musim yang lain dan musim timur mempunyai nilai SPL yang lebih kecil dibandingkan musim lainnya.

Karakteristik SPL di Kabupaten Pangandaran tahun 2018 berkisar antara $25^{\circ}-32,7^{\circ} \mathrm{C}$ sedangkan untuk besaran SPL yang dominan sebesar $27^{\circ}-31^{\circ} \mathrm{C}$. Besaran SPL di musim barat mempunyai nilai sebaran suhu terbesar dibandingkan musim lainnya dan musim timur mempunyai nilai sebaran SPL lebih kecil dibandingkan musim lainnya. Nilai SPL selama tiga tahun di Kabupaten Pangandaran berkisar antara $25^{\circ}-32^{\circ} \mathrm{C}$, sehingga ikan tenggiri mampu hidup di sepanjang musim di wilayah Kabupaten Pangandaran. Hal ini berdasarkan pernyataan Nahib (2010) yang menyatakan bahwa ikan tenggiri mampu hidup dengan rentan suhu $24^{\circ}-31^{\circ} \mathrm{C}$. Berdasarkan Rizkawati (2009) suhu mempunyai beberapa pengaruh terhadap kehidupan ikan yang ada perairan. 

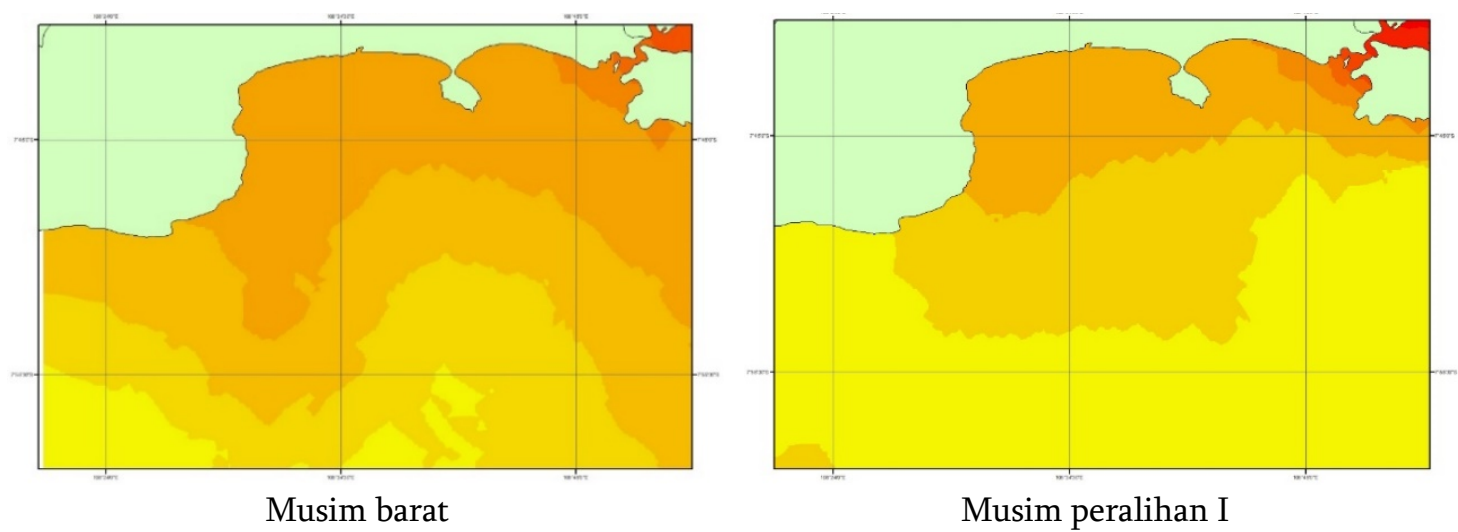

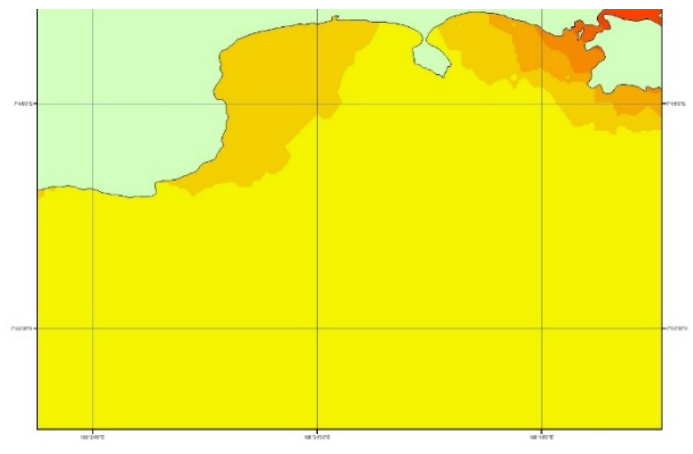

Musim timur

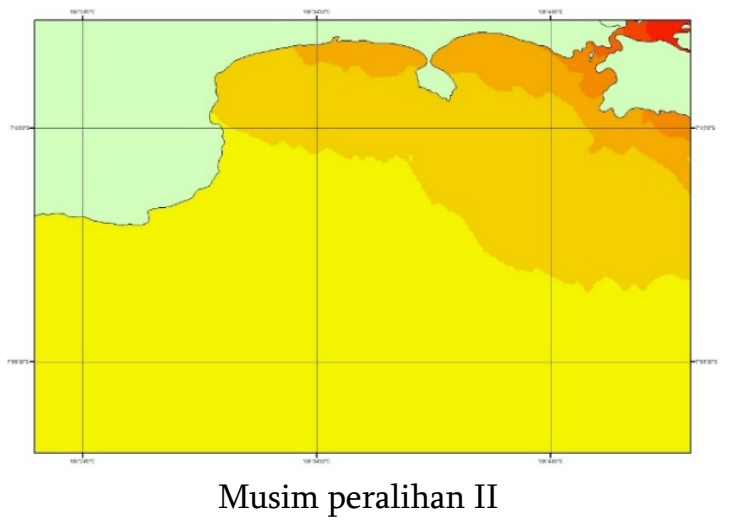

Musim peralihan II
$28,22-28,349$

$28,35-28,478$

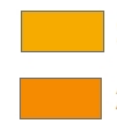

$28,479-28,607$

$28,608-28,736$
$28,737-28,865$

$28,866-28,994$
$28,995-29,123$

$29,124-29,252$

Gambar 7 SPL musiman perairan Kabupaten Pangandaran tahun 2018

Berdasarkan data sebaran suhu permukaan laut pada setiap musim pada tahun 2016 sampai dengan 2018 menunjukkan bahwa secara keseluruhan suhu permukaan laut di perairan Pangandaran selama empat musim cenderung stabil dan disetiap tahun mengalami penurunan pada musim timur (Juni-Agustus). Rendahnya SPL di musim timur disebabkan oleh posisi matahari yang berada di bagian utara bumi sehingga wilayah selatan memperoleh sinar matahari lebih sedikit. Selain itu, adanya kondisi upwelling dimana kondisi ini terjadi apabila terjadi penurunan SPL dengan anomali $>0,5^{\circ} \mathrm{C}$ dibawah rata-rata serta adanya pertemuan dua masa air yang berbeda dari arah barat yang mempunyai suhu lebih tinggi sedangkan dari arah timur mempunyai nilai SPL yang lebih rendah (Rahman dkk, 2019).

Pada musim timur kecepatan arus akan meningkat. Safitri dkk (2012) menyatakan di musim timur aliran arus dari timur ke barat searah dengan arah Arus Lintas Indonesia (Arlindo) yang bergerak dari timur (Pasifik) ke arah barat (Hindia) sehingga dapat memperkuat arus permukaan dan aliran Arlindo. Berdasarkan hasil analisis antara SPL dan arus, menunjukkan bahwa pada saat kecepatan arus meningkat, nilai SPL akan mengalami penurunan begitupun sebaliknya. Sehingga berdasarkan pernyataan tersebut, kondisi SPL di Pangandaran sesuai dengan pergerakan Arlindo yang bergerak di Indonesia.

Daerah penangkapan adalah salah satu faktor penting dalam menentukan berhasil atau tidaknya suatu usaha penangkapan. Perairan dapat tergolong sebagai Daerah Penangkapan Ikan (DPI) jika pada perairan tersebut terdapat ikan yang menjadi target utama penangkapan serta adanya teknologi penangkapan ikan yang digunakan untuk menangkap ikan. Penelitian yang dilakukan menggunakan perahu motor tempel dengan alat tangkap gillnet atau jaring insang. 
Kategori daerah penangkapan ikan potensial untuk ikan tenggiri digolongkan kedalam tiga kategori, yaitu potensial, sedang dan kurang potensial yang didasarkan pada beberapa indikator, diantaranya jumlah hasil tangkapan ikan, rata-rata ukuran ikan tenggiri yang tertangkap dan distribusi suhu permukaan laut.

Hasil dari penilaian DPI tenggiri di wilayah perairan Pangandaran dikategorkan sedang dan memenuhi beberapa kriteria. DPI ikan tenggiri serta daerah penangkapan ikan tenggiri potensial berada pada koordinat 108 $21^{\prime} 18^{\prime \prime}$ BT, $7^{\circ} 50^{\prime} 58^{\prime \prime}$ LS dan 108 $44^{\prime} 30^{\prime \prime}$ BT, $7^{\circ} 48^{\prime} 31^{\prime \prime}$ LS. Terdapat 15 titik koordinat dan mempunyai hasil akhir daerah potensial penangkapan ikan tenggiri berada di dua titik dan sisanya termasuk kategori sedang. Hal ini berdasarkan metode skoring yang dilakukan dengan melakukan penilaian terhadap empat parameter yang dihitung yaitu total hasil tangkapan, rata-rata panjang ikan dan suhu permukaan laut. Hasil penilaian daerah potensial ikan tenggiri di perairan Pangandaran disajikan pada Tabel 5.

Tabel 5 Penilaian DPI di Pangandaran

\begin{tabular}{ccccccc}
\hline No & Longitude & Latitude & $\begin{array}{c}\text { Hasil } \\
\text { Tangkapan }(\mathrm{Kg})\end{array}$ & $\begin{array}{c}\text { Ukuran } \\
(\mathbf{c m})\end{array}$ & SPL & Kategori DPI \\
\hline 1 & $108^{\circ} 18^{\prime} 55^{\prime \prime}$ & $7^{\circ} 51^{\prime} 00^{\prime \prime}$ & 1,95 & 52,3 & 25,2 & Sedang \\
2 & $108^{\circ} 18^{\prime} 35^{\prime \prime}$ & $7^{\circ} 51^{\prime} 00^{\prime \prime}$ & 12,9 & 58,6 & 25,4 & Sedang \\
3 & $108^{\circ} 21^{\prime} 18^{\prime \prime}$ & $7^{\circ} 50^{\prime} 58^{\prime \prime}$ & 21,13 & 65,47 & 26,4 & Potensial \\
4 & $108^{\circ} 27^{\prime} 00^{\prime \prime}$ & $7^{\circ} 50^{\prime} 11^{\prime \prime}$ & 0,95 & 25,5 & 25,8 & Sedang \\
5 & $108^{\circ} 33^{\prime} 00^{\prime \prime}$ & $7^{\circ} 42^{\prime} 30^{\prime \prime}$ & 12,37 & 65,3 & 25,3 & Sedang \\
6 & $108^{\circ} 32^{\prime} 45^{\prime \prime}$ & $7^{\circ} 42^{\prime} 30^{\prime \prime}$ & 6,9 & 57,9 & 26 & Sedang \\
7 & $108^{\circ} 33^{\prime} 10^{\prime \prime}$ & $7^{\circ} 43^{\prime} 30^{\prime \prime}$ & 3,9 & 54,6 & 25,7 & Sedang \\
8 & $108^{\circ} 39^{\prime} 45^{\prime \prime}$ & $7^{\circ} 45^{\prime} 45^{\prime \prime}$ & 15,05 & 58,3 & 25,6 & Sedang \\
9 & $108^{\circ} 39^{\prime} 58^{\prime \prime}$ & $7^{\circ} 45^{\prime} 45^{\prime \prime}$ & 6,5 & 56,4 & 25,3 & Sedang \\
10 & $108^{\circ} 43^{\prime} 30^{\prime \prime}$ & $7^{\circ} 45^{\prime} 40^{\prime \prime}$ & 1,4 & 25,3 & 25,7 & Sedang \\
11 & $108^{\circ} 43^{\prime} 45^{\prime \prime}$ & $7^{\circ} 45^{\prime} 41^{\prime \prime}$ & 10,54 & 57,6 & 25,6 & Sedang \\
12 & $108^{\circ} 44^{\prime} 57^{\prime \prime}$ & $7^{\circ} 47^{\prime} 46^{\prime \prime}$ & 6,5 & 56,37 & 25,3 & Sedang \\
13 & $108^{\circ} 44^{\prime} 30^{\prime \prime}$ & $7^{\circ} 48^{\prime} 31^{\prime \prime}$ & 17,85 & 65,33 & 25,7 & Potensial \\
14 & $108^{\circ} 44^{\prime} 30^{\prime \prime}$ & $7^{\circ} 49^{\prime} 00^{\prime \prime}$ & 22 & 64,9 & 26,2 & Sedang \\
15 & $108^{\circ} 42^{\prime} 30^{\prime \prime}$ & $7^{\circ} 48^{\prime} 28^{\prime \prime}$ & 0,85 & 25 & 25,5 & Sedang \\
\hline
\end{tabular}

Daerah yang optimum untuk penangkapan ikan tenggiri berada pada koordinat $108^{\circ} 21^{\prime} 18^{\prime \prime} \mathrm{BT}$, $7^{\circ} 50^{\prime} 58^{\prime \prime}$ LS dan 108 $44^{\prime} 30^{\prime \prime}$ BT, $7^{\circ} 48^{\prime} 31^{\prime \prime}$ LS dan tiga belas lokasi lainnya termasuk kategori sedang. Secara garis besar hasil tangkapan di semua titik tidak memenuhi kriteria DPI ikan tenggiri yang baik namun untuk faktor lain seperti panjang ikan dan sebaran suhu permukaan laut memenuhi kriteria, hal ini disebabkan pada saat kegiatan penelitian, cuaca yang kurang mendukung seperti besarnya gelombang pada saat kegiatan mencari ikan yang menyebabkan penghasilan atau hasil tangkapan ikan tenggiri berkurang. Hal ini juga dapat dikaitkan dengan sub bab pembahasan dimana klorofil-a serta suhu permukaan laut tidak mempunyai korelasi yang kuat sehingga meski kedua parameter ini sesuai 
untuk habitat ikan tenggiri hasil tangkapannya rendah. Gambaran pendugaan daerah potensial penangkapan ikan tenggiri di perairan Pangandaran disajikan pada Gambar 8.

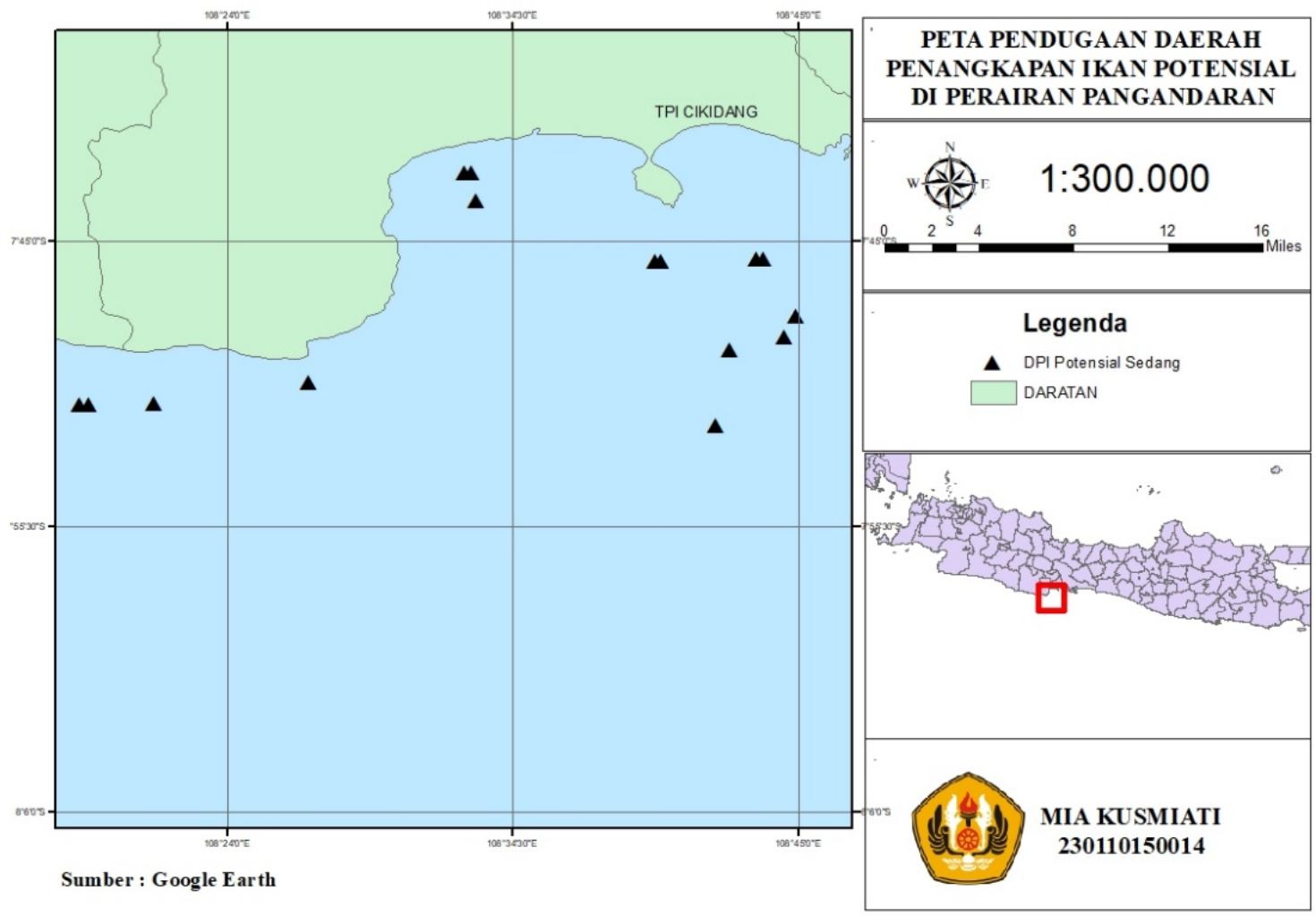

Gambar 8 Peta DPI ikan tenggiri

\section{KESIMPULAN DAN SARAN}

Berdasarkan hasil penelitian yang telah dilakukan, maka dapat disimpulkan bahwa daerah penangkapan potensial untuk ikan tenggiri di wilayah perairan Kabupaten Pangandaran berada pada koordinat 108 $21^{\prime} 18^{\prime \prime}$ BT, $7^{\circ} 50^{\prime} 58^{\prime \prime}$ LS dan 108 $44^{\prime} 30^{\prime \prime}$ BT, $7^{\circ} 48^{\prime} 31^{\prime \prime}$ LS.

\section{DAFTAR PUSTAKA}

Almuthahar A. 2005. Analisis Suhu Permukaan Laut dan Klorofil-a Dari Data Satelit Dan Hubungannya Terhadap Hasil Tangkapan Ikan Kembung (Rastrelliger sp) Di Perairan Natuna-Laut Cina Selatan [Tesis]. Bogor: Institut Pertanian Bogor.

Apriliani IM, Dwipayana MF, Sunarto, Rostini I. 2019. Catch Comparison and Rata of Floating Liftnet at Different Time of Hauling in Pangandaran, West Java, Indonesia. World News of Natural Sciences. 22: 168-173.

Azwar S. 2010. Metode Penelitian. Yogyakarta: Pustaka Pelajar.

Dinas Kelautan dan Perikanan Kabupaten Pangandaran 2017. Laporan Tahunan Dinas Perikanan dan Kelautan Kabupaten Pangandaran. Dinas Perikanan dan Kelautan Pangandaran. Pangandaran.

Jumsurizal, AN dan M. Kurnia. 2014. Produktivitas Penangkapan Ikan Tenggiri (Scomberomorus commerson) Menggunakan Pancing Ulur di Perairan Kabupaten Bintar. Jurnal IPTEK PSP. 1(2): 165-173. 
Mutakin J. 2001. Analisis Potensi dan Musim Penangkapa Ikan Tenggiri (Scomberomorus sp) di Pangandaran Kabupaten Ciamis, Jawa Barat [Skripsi]: Institut Pertanian Bogor.

Nahib DS, A.D. Suriadi, Niendyawati dan Rahadiati. 2010. Prediksi sebaran Fishing Ground Menggunakan Data Modis Multitemporal, Oseanografi dan Kearifan Lokal Divalidasi dengan Hasil Tangkapan Real yang Terplot Spasial. Bogor (ID): Bakosurtanal.

Putra, E. 2012. Variabilitas Konsentrasi Klorofil-a dan Suhu Permukaan Laut Dari Citra Satelit Modis Serta Hubungannya Dengan Hasil Tangkapan Ikan Pelagis Di Perairan Laut Jawa. Bogor: FPIK, IPB.

Rahman, M. A., M. Laksmini., U. K. Agung., dan Sunarto. 2019. Pengaruh Musim Terhadap Kondisi Oseanografi Dalam Penentuan Daerah Penangkapan Ikan Cakalang (Katsuwonus pelamis) di Perairan Selatan Jawa Barat. Jurnal Perikanan dan Kelautan. 10 (1): 92-102.

Restianingsih, H. Yoke., T, Noegroho dan K. Wagiyo. 2016. Beberapa Aspek Biologi Ikan Tenggiri Papan (Scomberomorus guttatus) di Perairan Cilacap Dan Sekitarnya. Ejournal balitbang. 8 (3): $191-198$.

Rizkawati, R. 2009. Pengaruh Suhu Permukaan Laut Terhadap Hasil Tangkapan Ikan Tenggiri Di Perairan Indramayu Jawa Barat. [Skripsi]. Fakultas Perikanan dan Ilmu Kelautan: Institut Pertanian Bogor.

Safitri, M., Cahyani, S.Y dan Putri, M. R. 2012. Variasi Arus Arlindo dan Parameter Oseanografi di Laut Timor Sebagai Indikasi Kejadian ENSO. Jurnal llmu dan Teknologi Kelautan Tropis. 4 (2): 369377.

Tangke, Umar., J.C. Karuwal., M. Zainuddin dan A. Mallawa. 2012. Analisis Hubungan Faktor Oseanografi Dengan Hasil Tangkapan Ikan Tenggiri (Scomberamorus sp) di Perairan Kecamatan Leihitu Kab. Maluku Tengah. Jurnal Ilmiah agribisnis dan Perikanan. 5 (2): 21-24. 